\title{
PENDEKATAN KEAGAMAAN MEDIATOR TERHADAP PARA PIHAK DALAM PERKARA PERCERAIAN DI PENGADILAN AGAMA
}

\author{
Karmawan \\ UIN Syarif Hidayatullah Jakarta DPK \\ Universitas Syeikh Yusuf Tangerang \\ karmawan@unis.ac.id
}

\begin{abstract}
The religious knowledge possessed by the mediator becomes the basis for the case in the religious court, the religious court provides space for the mediator to improve his ability so that the mediated case is not in the form of a decision from a panel of judges but in the form of a peace deed. The mediator uses a religious approach to be understood by the parties considering separating. Because the religious approach is considered more rational in the family problem back to the teachings of Islam, not disagree with each other. The mediator of the religious court provides religious knowledge in the form of advice to the parties in the event of a divorce which is certainly sacrificed by the problems of the position of husband and wife, issues of property and status of children who are victims of the separation of their parents.
\end{abstract}

Kata Kunci : Religious approach, Mediator, divorce, religious courts 


\section{Pendahuluan}

Meningkatnya perkara perdata Islam di pengadilan agama dan semakin banyaknya perkara yang di putus oleh majelis hakim, setidaknya pelaksanaan mediasi dan peran mediator bisa mengurangi putusan perkara yang terjadi terhadap para pihak yang berperkara. Mediator yang profesional dari kalangan akademisi, agamawan dan praktisi dapat membantu pengadilan agama mengisi sebagai mediator sebelum perkara diputus oleh majelis hakim, dan mengurangi beban hakim mendominasi putusan dan juga mengurangi dampak negatif akibat persengketaan.

Menjadi mediator sebagai juru damai di pengadilan agama, bukan sebuah perkara yang mudah, karena akan berhadapan secara langsung dengan para pihak-pihak yang berbeda karakter. Sehingga peran mediator dijalankan secara maksimal untuk menciptakan komunikasi yang efektif dengan para pihak. Komunikasi yang efektif akan terbentuk jika mediator dapat memahami para pihak. Berbagai pendekatan harus dimiliki mediator diantaranya pendekatan dari aspek pengetahuan agama yang dimiliki. Pengetahuan keagamaan memberikan kesadaran terhadap pihak yang berperkara sehigga mengurungkan niatnya untuk bercerai.

Perkara perceraian di pengadilan agama yang melibatkan mediator sebagai juru damai menjadi kewajiban yang harus ditempuh oleh para pihak, karena tugas mediator hanya sebatas mengetahui informasi permasalahan yang terjadi terhadap kedua belah pihak bukan memutus perkara. Adapun tugas mediator tertera dalam PerMA nomor 1 tahun 2016 dalam pasal 14 yang 
|Karmawan

menjelaskan di dalamnya bahwa tugas mediator memfasilitasi dan mendorong Para Pihak untuk:1) menelusuri dan menggali kepentingan Para Pihak; 2. mencari berbagai pilihan penyelesaian yang terbaik bagi Para Pihak; dan 3.bekerja sama mencapai penyelesaian; Di lain pihak seorang mediator harus memiliki kemampuan yang sangat mendasar seperti dilihat dari kemampuan kecakapan mediator untuk membantu para pihak berkomunikasi secara jelas permasalahan yang dihadapinya. Karena permasalahan yang disembunyikan oleh pihak-pihak yang bersengketa tentu akan mempersulit mediator untuk berkomunikasi memberikan pemahaman bahkan penjelasan terhadap perkara yang disengketakan.

Mengingat peran mediator mendamaikan pihak-pihak yang berperkara terbatas sampai anjuran, nasihat, penjelasan dan memberi bantuan dalam perumusan sepanjang hal itu diminta kedua belah pihak. Oleh karena itu, hasil perdamaian harus benar-benar hasil kesepakatan kehendak bebas dari kedua belah pihak. Hal inilah yang harus dipahami dan disadari oleh mediator dalam melaksanakan fungsi mendamaikan, dan jangan sampai terjadi bentuk perdamaian dihasilkan tindakan belah bambu yang berisi materi kehendak mediator atau kehendak sepihak dari pihak yang kuat.

Tampak jelas bahwa mediasi masih menggunakan pendekatan yang sifatnya tradisional. Mediator di pengadilan agama masih menggunakan aspek pendekatan yang lazim digunakan saat menyelesaikan sengketa secara adat dalam masyarakat, seperti memberikan penyuluhan bagi pasangan di BP4, maupun dalam persidangan. Secara teknis, strategi mediasi 
yang dilakukan mediator di pengadilan agama dalam mempengaruhi pihak yang berperkara pada umumnya berpusat pada metode pendekatan keagamaan. Dengan memberikan penjelasan perkara kepada para pihak yang berperkara baik yang ada dalam al-Qur'an dan Hadits Nabi sebagai sumber utama hukum Islam, dan sumber hukum yang berlaku di Indonesia berupa undang-undang No.1 Tahun 1974.

\section{Pendekatan keagamaan Mediator}

Pendekatan keagamaan oleh mediator terhadap pihakpihak yang berperkara sebagai nilai da'wah untuk mengajak para pihak untuk mengembalikan semua perselisihan rumah tangga dalam konteks agama. Penulis menganalis bahwa mediator dengan metode pendekatan keagamaan yang diberikan untuk mempengaruhi hati para pihak yang berperkara. Selanjutnya mediator juga menyebutkan bahwa pemberian pendekatan sosial keagamaan disesuaikan dengan kebutuhan permasalahan yang mereka hadapi. Memahami situasi suami isteri merupakan kewajiban mediator dalam rangka menciptakan damai dan rekonsiliasi dalam keluarga yang bersengketa. Dengan demikian, mediator dapat menciptakan situasi yang menyebabkan kedua belah pihak sadar akan perbuatannya serta dapat menumbuhkan keinginan untuk menciptakan keluarga yang harmonis.

Bahwa untuk mengukur tingkat efektifitas pendekatan keagamaan dalam proses mediasi bukan dimaksudkan untuk mendamaikan para pihak, karena hal tersebut jarang dan sulit terjadi. Akan tetapi efektifitas pendekatan keagamaan dirasa efektif untuk menambah wawasan para pihak yang berperkara. 
Hal tersebut terbukti bahwa para pihak mereka berargumen bahwa hati mereka merasa terbuka dan lega setelah mendengar nasehat-nasehat agama yang diberikan oleh mediator, mereka juga bertekad untuk menjalankan rumah tangga yang lebih baik sesuai dengan nilai hukum perkawinan dalam Islam. Para mediator berharap para pihak mendapatkan manfaat dan hikmah dari pendekatan keagamaan tersebut.

Dalam hal ini mediator berperan sebagai tokoh agama yang memberikan nasehat-nasehat spiritual kepada para pihak yang berperkara untuk memikirkan kembali putusannya. Mediator berusaha melakukan dakwah untuk memberi dan memperingatkan para pihak menjadi lebih baik. Meskipun demikian, para mediator tidak semena-mena memaksa para pihak sesuai dengan keinginan para mediator. Keberadaan mediator sangat penting menengahi suami istri yang berperkara. Bahkan Al-Qur'an juga menjelaskan beban dan tanggung jawab mediator dalam sengketa keluarga cukup penting, terutama ketika suatu keluarga sudah menunjukkan tanda-tanda adanya perselisihan, maka pihak keluarga dari pihak suami atau isteri sudah dapat mengutus mediator.

Nilai-nilai dan nasehat agama terutama yang diberikan oleh mediator kepada para pihak diharapkan mampu memberi pengaruh yang positif terhadap kehidupan rumah tangga suami isteri tersebut. Pada dasarnya tekanan agama yang diberikan oleh mediator sangat berpengaruh penting untuk mempengaruhi hati suami isteri yang bersengketa, hal tersebut dikarenakan oleh hati yang kurang akan siraman rohani, wawasan dan wacana keislaman-lah yang diharapkan mampu untuk mempengaruhi hati 
tersebut. Dengan demikian, pendekatan agama dapat dijadikan sebagai bekal para pihak suami isteri untuk membina keutuhan rumah tangga di kemudian hari.

Seperti halnya mediator memberikan nasehat perkawinan terhadap para pihak yang bersengketa. karena perkawinan dianggap sebagai ikatan sakral yang mengikat kedua pasangan suami istri. Mediator memberikan penjelasan dan pelajaran tentang arti dan pentingnya sebuah perkawinan yang merupakan bentuk realisasi ibadah kepada Allah, serta hikmah dari perkawinan yang membentuk keluarga sakinah, mawaddah, dan penuh rahmah sampai akhir hayat. Jika terjadi percekcokan bahkan pengajuan gugatan Perceraian ke pengadilan adalah sebagai "pintu darurat" jika kedua pasangan tidak lagi dapat menyelesaikan permasalahan mereka. Secara tidak langsung peran mediator juga merangkap sebagai educator, dimana dalam proses ini para pihak dibekali ilmu pengetahuan tentang hak dan kewajiban suami istri dalam hukum Islam sesuai dengan mazhab yang diyakini oleh sang mediator. Jika upaya damai tidak dapat dilakukan, hal ini akan membekali pasangan agar tidak terjadi lagi saat mereka mengarungi bahtera perkawinan untuk kedua kalinya.

Perkawinan merupakan suatu ikatan antara seorang suami dan istri untuk membentuk rumah tangga yang sakinah dan mawadah dalam sebuah ikatan perkawinan. Tujuan dilaksanakannya perkawinan adalah membentuk rumah tangga yang bahagia, sakinah, dan mawadah. Sebuah hadis Nabi Saw menerangkan bahwa perceraian adalah peristiwa yang tidak disukai oleh Allah. Oleh karena itu, perceraian bukan tujuan 
perkawinan itu sendiri. Keluarga sakinah pada hakikatnya adalah keluarga model Islam yang diinspirasikan dalam al-Qur'an, "jagalah dirimu dan keluargamu dari api neraka". Zaitunah Subhan lebih lanjut menjelaskan bahwa cara yang perlu dilakukan untuk mencapai keluarga sakinah adalah membekali diri dengan pengetahuan, informasi, potensi, dan pengetahuan. Itu merupakan prasyarat mutlak dari keluarga model tersebut. Meskipun perjalanan dalam menempuh kehidupan rumah tangga yang sakinah sering diwarnai dengan ketidakcocokan satu sama lain yang berujung pada perceraian.

Terkait dengan keberhasilan mediasi yang dilakukan pengadilan agama, pendekatan yang digunakan dalam melakukan mediasi adalah mengembalikan para pemohon ke dalam tujuan utama perkawinan yang merupakan perintah agama sehingga pemohon mengurungkan niatnya untuk berperkara. Para pemohon diajak untuk memahami kembali tujuan perkawinan dalam pandangan agama Islam. Kesadaran yang dibangun sangat penting agar mereka kembali hidup rukun. Hidup rukun dalam sebuah perkawinan merupakan ajaran agama Islam yang merupakan esensi perkawinan.

Hakikat perkawinan yang dikehendaki oleh agama Islam disampaikan secara verbal dengan pendekatan persuasif kepada kedua belah pihak. Hal tersebut harus didorong agar dihayati kembali terutama oleh pemohon. Informasi tersebut disampaikan dengan pendekatan personal agar dapat diresapi secara baik oleh pemohon. Cara ini dapat menghasilkan hasil optimal. Dengan cara ini pemohon dapat mengurungkan niatnya untuk bercerai. Untuk mencegah terjadinya hal tersebut, para pihak diberikan 
pencerahan atau nasehat keagamaan tentang makna sebuah pernikahan (marriage counseling), agar para pihak memiliki pemahaman pernikahan yang sakral, dan mampu untuk mengendalikan diri dari konflik rumah tangga.

Proses mediasi yang dilaksanakan mediator diharapkan mampu mendamaikan atau memperbaiki hubungan para pihak yang hendak bercerai demi menciptakan rumah tangga yang utuh. Keberadaan mediator untuk menyelesaikan sengketa keluarga sangat urgen. Mediator dalam perkara keluarga dapat mengidentifikasi setiap persoalan, dan mencari jalan keluar serta menawarkan kepada suami isteri yang bersengketa. Tindakan yang ditempuh oleh mediator harus dengan hati-hati, karena persoalan keluarga dianggap persoalan sensitif dan membutuhkan konsentrasi penuh, demi untuk merekatkan hubungan yang retak. Memahami situasi suami isteri merupakan kewajiban mediator dalam rangka menciptakan damai dan rekonsiliasi dalam keluarga yang bersengketa. Dengan demikian, mediator dapat menciptakan situasi yang menyebabkan kedua belah pihak percaya dan tumbuh keinginan untuk bersatu kembali mempertahankan rumah tangga.

Secara umum pendekatan sosial keagamaan menjadi faktor dalam mediasi kedua belah pihak, agar menjadi pertimbangan putusan dihadapan hajelis hakim secara adil dan bijaksana. Karena mengedepankan ajaran agama dalam perselisihan lebih banyak maslahatnya. Strateginya adalah menjelaskan baik melalui al-Qur'an atau pun hadits Nabi bahwa permasalahan dalam hukum Islam berkaitan perkara perceraian, warisan ataupun harta bersama diselesaikan dengan perselisihan tidak membuat baik terhadap pihak-pihak yang bertikai, Oleh 
|Karmawan

karena itu, seorang mediator harus menyamakan kedudukan antara kedua belah pihak yang bersengketa dalam persidangan, mediator harus mendengarkan penjelasan keduanya dalam menyelesaikan masalah tidak hanya satu pihak, untuk memulai persidangan, seorang mediator harus memulai dari penggugat untuk menjelaskan permasalahannya apabila orang yang tergugat itu mengingkarinya. maka dengan proses mediasi melalui pendekatan sosial keagamaan dapat terselesaikan dengan baik. Adapun pembahasan mediasi dengan pendekatan keagamaan yang dilaksanakan oleh mediator menjadi materi seorang mediator terhadap para pihak yang berperkara. Adapun materi pendekatan keagamaan tersebut antara lain adalah:

\section{Terhadap suami istri}

Dengan adanya perceraian, setelah keputusan hakim didaftarkan dalam daftar catatan sipil, maka tidak ada kewajiban untuk hidup bersama antara bekas suami dan istri, dengan kata lain mereka hidup terpisah secara sendiri-sendiri. Akibatnya si istri menjadi cakap untuk bertindak sendiri, bekas istri dapat melakukan tindakan hukum tanpa bantuan suami. Masalah pemberian tunjangan nafkah, dalam pasal 225 KUHPerdata menentukan kepada pihak yang menang dalam perkara perceraian itu ada kemungkinan untuk mendapatkan nafkah dari pihak yang kalah, bilamana ia tidak mempunyai penghasilan yang cukup. Pasal 329 KUH Perdata menentukan bahwa dalam hal menentukan jumlah uang nafkah, maka hakim harus menentukan imbangan antara kebutuhan pihak yang menuntut nafkah itu, dengan pendapatan serta kekayaan pihak yang dituntut, dihubungkan dengan jumlah dan keadaan orang-orang lain yang 
harus diberi nafkah olehnya. Pemberian tunjangan tersebut dapat berakhir, dengan menikahnya bekas isteri dengan pihak lain. Hal ini berdasarkan pertimbangan bahwa bekas isteri dengan menikahnya lagi dengan pihak lain telah berarti memilih suatu jalan baru, suatu hidup baru, maka logis apabila suami yang baru pula menjamin kesejahteraan hidupnya.

Perkara perceraian seorang mediator menjelaskan jika terjadi perceraian antara kedua belah pihak akan mengakibatkan berhentinya pemberian nafkah terhadap isteri karena akibat dari perceraian silaturrahim antara keduanya bahkan keluarga besar akan terjadi permasalahan dikemudian hari bahkan terhenti dan saling bermusuhan antara keduanya. Pada umumnya hakim mediator menjelaskan berkaitan dengan nafkah pasca perceraian yang terjadi mantan suami mempunyai kewajiban memberikan nafkah kepada mantan istri selama ia menjalani masa idah. Kewajiban mantan suami untuk memberi nafkah kepada mantan istri tercantum dalam Q.S. Al-Talaq [65]: 6 dan 7. Para fuqaha mazhab empat menetapkan beberapa syarat terhadap mantan istri untuk mendapatkan nafkah selama masa idah dari mantan suami: Pertama, istri ditalak raj'i; dan kedua, mantan istri tidak nushuz. Dalam peraturan perundang-undangan yang berlaku di Indonesia, baik dalam UU perkawinan maupun dalam KHI, istri yang ditalak oleh suaminya berhak memperoleh nafkah selama idah. Dalam Pasal 41 huruf c UU perkawinan, hakim dapat menentukan biaya hidup untuk istri yang dijatuhi talak oleh suaminya. Demikian halnya dalam Pasal 149 huruf b dan Pasal 152 KHI, mantan istri yang dicerai suaminya berhak memperoleh nafkah selama masa idah selama mantan istri tersebut tidak nushuz. 
Sebagaimana dalam perkawinan yang memuat hak dan kewajiban antara suami dan istri, demikian juga jika terjadi perceraian maka ada akibat hukum darinya. Hal ini untuk menjaga adanya keseimbangan dan keadilan, sebab ketika mereka pertama kali melangsungkan perkawinan sehingga ketika berpisah pun juga harus secara baik-baik. Salah satu tujuan dibuat Undang-undang adalah untuk melindungi hak-hak istri (wanita) sebab terjadinya perceraian yang tentunya merupakan peristiwa yang menyakitkan bagi wanita seharusnya tidak lagi membawa penderitaan terlalu dalam, jika ia mendapatkan haknya yang seharusnya ia dapat. Dengan adanya Undang-undang tersebut diharapkan, salah satunya adalah hak-hak istri dapat terlindungi, hal ini tentunya merupakan unsur penunjang yang secara yuridis sangat kuat landasannya, karena di dalamnya memuat hak-hak yang dapat diterima oleh istri sebagai akibat dari peceraian.

\section{Permasalahan Anak}

Anak merupakan buah perkawinan yang paling utama. Akibat peristiwa perceraian, dampak yang dirasakan oleh anak sangat besar. Secara psikologis, seorang anak hidup dalam lingkungan keluarga yang broken home memiliki dampak yang sangat besar. Kepribadian anak menjadi pecah akibat perceraian orang tua. Perceraian merupakan pencipta stres terbesar bagi anak, baik pada saat praperceraian, masa transisi perceraian, dan pada masa pascaperceraian. Oleh karena itu, hal tersebut dapat dijadikan dasar dan pertimbangan dalam penanganan mediasi. Para pemohon diminta untuk berpikir mendalam mengenai masa depan dan kehidupan anak pascaperceraian. Secara umum, pendekatan ini menghasilkan hasil positif dalam mediasi perkara 
perceraian. Para pemohon mengurungkan niatnya dikarenakan kekhawatiran akan masa depan kehidupan anak. Hakim mediator di wilayah hukum Pengadilan Tinggi Agama Provinsi Banten menggunakan pendekatan ini sebagai strategi mediasi untuk menyelesaikan perkara.

Anak yang memiliki keluarga broken home biasanya mengalami split of personality. Dalam keadaan seperti ini, kepribadian dan emosi mereka sangat labil, yang secara umum hal tersebut dapat menyebabkan terjadi perilaku menyimpang pada anak. Bagi pemohon yang belum dikaruniai anak, pendekatan ini tidak digunakan. Hakim mediator selalu menyampaikan dampak negatif terhadap anak akibat perceraian orang tua kepada pemohon yang berperkara sebagai suatu strategi mediasi. Dalam proses mediasi agar kedua belah yang berselisih memandang anak yang dikhawatirkan setelah terjadinya perceraian anak akan telantar dan kurang kasih sayang dari bapak ibunya yang akhirnya si anak ini melakukan hal-hal di luar dugaaan orang tua, penyebab kurangnya perhatian karena orang tuanya bercerai, secara psikologis perkembangan anak tidak seperti anak yang utuh kedua orang tuanya. Dengan melihat anak maka hakim mediator pun memberikan jalan solusi agar menempuh jalan damai karena alasan anak. Disisi lain, dampak perceraian akan menjadikan anak menjadi rendah konsep dirinya, kemampuan akademik, dan anti sosial. Kemampuan akademik anak-anak apabila diuji dengan menggunakan tes potensi akademik dan tes skolastik, hasilnya akan berada di bawah rata-rata. Perilaku anti sosial yang ditimbulkan menjadikan anak tidak disiplin dan nakal. Pemohon yang telah 
memahami dampak tersebut lebih memilih jalan perdamaian melalui mediasi.

Perceraian orang tua juga akan berdampak pada psikologi mental dan emosi anak, emosi merupakan situasi pengalaman subjektif yang dapat dilihat dari reaksi wajah dan tubuh. Oleh karena itu pengalaman yang buruk akan berdampak pada perkembangan emosi anak yang kurang baik. Peristiwa perceraian tersebut menimbulkan ketidakstabilan emosi bagi anak. Perceraian orang tua membuat tempramen anak terpengaruh. Pengaruh yang tampak secara jelas dalam perkembangan emosi itu adalah membuat anak menjadi pemurung, pemalas (menjadi agresif) yang ingin mencari perhatian orang lain.

Di sisi lain, Emery menerangkan hasil penelitiannya bahwa perceraian akan berpengaruh terhadap kesehatan mental keluarga, khsusunya kesehatan mental anak (chiledren's mental health). Kesehatan mental anak meliputi kesehatan fisik, intelektual, dan emosional. Menurut kesepakatan para ahli, kesehatan mental diklasifikasikan sebagai Diagnostic and Statistical Manual of Mental Disorder revisi III pada tahun 1980. Disitu disebutkan bahwa gangguan kesehatan mental pada anak akan menyebabkan retardasi mental, hiperaktif, kecemasan pada anak, penyimpangan perilaku makan (anoreksia), dan semua perkembangan anak (fisik, intelektual, dan emosional). Zakiah Daradjat menerangkan empat rumusan mengenai kesehatan mental, yaitu: pertama, kesehatan mental adalah terhindarnya orang-orang dari gejala-gejala gangguan jiwa (neurose) dan dari gejala-gejala penyakit jiwa (psychose). Kedua, kesehatan mental 
adalah kemampuan untuk menyesuaikan diri dengan diri sendiri, dengan orang lain, dan dengan masyarakat serta lingkungan sekitar. Ketiga, kesehatan mental adalah pengetahuan dan perbuatan yang bertujuan untuk mengembangkan dan memanfaatkan segala potensi, bakat, dan pembawaan yang ada semaksimal mungkin sehingga membawa pada kebahagiaan diri dan orang lain, sehingga terhindar dari gangguan dan penyakit jiwa. Keempat, kesehatan mental adalah terwujudnya keharmonisan yang sungguh-sungguh antara fungsi-fungsi jiwa, serta mempunyai kesanggupan untuk menghadapi problemproblem yang biasa terjadi dan merasakan secara positif kebahagiaan dan kemampuan dirinya.

Andrew J. Cherlin, P. Lindsay Chase-Lansdale dan Christine McRae (1998), menerangkan bahwa perceraian orang tua dapat mengakibatkan dampak negatif terhadap anak sampai usia dua puluh tahun dan usia tiga puluh tahunan awal. Penelitian dalam bidang psikologi perkembangan menunjukkan bahwa dampak perceraian akan menyebabkan depresi bagi anak hingga mencapai usia dewasa. Penyimpangan perilaku secara eksternal yang terjadi pada anak adalah perilaku agresif dan ketidaktaatan pada aturan, sedangkan secara internal akan menyebabkan kecemasan dan depresi pada anak hingga usia dewasa.

Dengan adanya pengertian dan rumusan di atas mengenai kesehatan mental, dapat terlihat jelas dampak negatif perceraian terhadap kondisi kesehatan mental anak. Oleh karenanya Hakim mediator dalam kaitan ini melakukan terapi terhadap pemohon sehingga dampak negatif perceraian bagi anak dapat dihayati sehingga tidak terjadi. Dalam arti bahwa para pemohon/pihak 
yang berperkara mengurungkan niatnya dan melakukan perdamaian melalui mediasi yang difasilitasi oleh hakim mediator pengadilan.

Willson Nadeeh (1992) menyatakan bahwa anak sulit menyesuaikan diri dengan lingkungan. Anak yang dibesarkan keluarga pincang cenderung sulit menyesuaikan diri dengan lingkungan. Kesulitan itu datang secara alamiah dari diri anak. Anak akan menjadi minder untuk bergaul dengan lingkungan sosialnya karena merasa malu dengan keadaan rumah tangga orang tuanya. Hal ini merupakan dampak sosial terburuk dalam perjalanan kehidupan anak. Oleh karena itu kondisi semacam ini menjadi alat bagi mediator dalam menyelesaikan perkara para pihak. Artinya perkembangan sosial anak sebagai dampak perceraian harus menjadi perhatian serius.

Perkembangan kepribadian anak sangat dipengaruhi oleh keadaan orang tua. Erikson (1992) mengidentifikasi bahwa rasa takut, prasangka, dan keprihatinan yang terjadi dalam diri anak akan berdampak pada perkembangan kepribadian anak pada usia berikutnya. Westima dan Haller menerangkan bahwa remaja yang orang tuanya bercerai cenderung menunjukkan: 1). Berpilaku nakal, 2). Mengalami defresi, 3). Melakukan hubungan seksual secara aktif. 4). Kecenderungan pada obat-obatan terlarang.

Guang Guo dan Kathleen Mullan Harris (2000) mengutip dampak perceraian terhadap perkembangan intelektual anak. Disamping dampak terhadap perkembangan keperibadian, dampak terhadap perkembangan intelektual juga kurang menunjukkan sisi positif. Disebutkan bahwa dampak perceraian bagi perkembangan intelektual anak dapat dipicu oleh adanya 5 
(lima) faktor, yaitu rangsangan kognitif, pola asuh, lingkungan fisik, kesehatan anak pada masa kelahiran dan masa pertumbuhan. Kelima faktor pemicu tersebut muncul akibat perceraian. Kelima faktor pemicu tersebut mendorong penurunan faktor intelektualitas anak.

Di sisi lain, dampak perceraian secara sosial akan melahirkan norma sosial yang negatif terhadap perkawinan. Mengutip pendapat Albert Bandura (2005) dalam Sosial Learning Theory, bahwa anak akan melakukan dan mengikuti melakukan perbuatan melalui apa yang saksikan (proses imitasi). Seorang anak yang berasal dari keluarga yang tidak harmonis dan orang tua yang bercerai akan melihat perceraian merupakan jalan terbaik dalam menyelesaikan permasalahan keluarga. Hal ini akan melahirkan pandangan dan norma yang negatif terhadap kehidupan keluarga yang tidak harmonis sehingga mengambil jalan perceraian dalam menyelesaikan masalah.

Dengan demikian, dampak yang kurang baik terhadap perkembangan kepribadian orang tua akibat perceraian orang tua menjadi sarana bagi mediator untuk digunakan sebagai strategi untuk melakukan mediasi bagi pihak yang berperkara. Dengan penghayatan terhadap dampak perceraian tersebut para pemohon mengurungkan niatnya untuk berperkara dan memilih jalan berdamai untuk hidup rukun kembali dalam pernikahan.

\section{Anak di bawah umur}

UU No 1 Tahun 1974 Pasal 1 disebutkan bahwa "tujuan perkawinan adalah membentuk keluarga (rumah tangga) yanng bahagia, kekal berdasarkan Ketuhanan Yang Maha Esa" senada 
pula dengan bunyi Pasal 3 KHI bahwa tujuan perkawinan adalah" untuk mewujudkan kehidupan rumah tangga yang sakinah, mawaddah, dan rahmah".

Begitu indah dan mulia tujuan perkawinan itu. Akan tetapi ternyata untuk mencapai dan mewujudkan tujuan tersebut tidaklah segampang yang diucapkan, tidaklah semudah yang diangankan. Karena manakala setelah perkawinan itu dijalani, banyak duri menghalangi, kerikil dan karang terjal menghadang,ombak dan gelombang pasang menerjang, maka biduk yang bernama rumah tangga itupun kerap tenggelam dan ahirnya karam. Maka ketika sebuah biduk perkawinan telah usai, dan penumpangnya bercerai berai, yang tersisa tinggallah puingpuing permasalahan. dan yang paling menderita akibat karamnya sebuah biduk perkawinan adalah anak.

Dengan jatuhnya putusan perceraian, mempunyai akibat pula terhadap kekuasaan orang tua berakhir dan berubah menjadi perwalian itu terhadap anak-anak yang masih di bawah umur. Penetapan wali oleh hakim dilakukan setelah mendengar keluarga dari pihak ayah maupun dari pihak ibu yang rapat hubungannya dengan anak tersebut. Hakim merdeka untuk menetapkan ayah atau ibu menjadi wali, tergantung dari siapa yang dipandang paling cakap atau baik mengingat kepentingan anak-anak. Penetapan wali ini juga dapat ditinjau kembali oleh hakim atas permintaan ayah atau ibu berdasarkan perubahan keadaan.

Dalam undang-undang perkawinan unsur suami isteri, harta kekayaan dan anak-anak merupakan unsur yang dilindungi sebagai mana pula halnya dalam KUH Perdata, hanya dalam Undang-undang perkawinan Nomor 1 tahun 1974 kedudukan 
anak lebih terjamin, sebagaimana ditegaskan dalam pasal 41 akibat putusnya perceraian adalah:

1. Baik ibu atau bapak tetap berkewajiban memelihara dan mendidik anak-anaknya, semata-mata berdasarkan kepentingan anak, bilamana ada perselisihan mengenai penguasaan anak, pengadilan memberi keputusannya.

2. Bapak yang bertanggung jawab atas semua biaya pemeliharaan dan pendidikan yang diperlukan anak itu, bilamana bapak dalam kenyataan tidak dapat memberi kewajiban tersebut, pengadilan dapat menentukan bahwa ibu ikut memikul biaya.

3. Pengadilan dapat mewajibkan kepada bekas suami untuk memberikan biaya penghidupan dan/atau menentukan sesuatu kewajiban bagi bekas isteri.

Meskipun dari uraian di atas tampaknya perkembangan anak terjadi dengan lancar dan sederhana, tetapi kenyataannya tidaklah demikian. Kemampuan yang kelihatannya sangat sederhana diperoleh anak dengan susah payah melalui usahanya yang tidak kenal jemu dan putus asa, yang diulangnya berpuluh bahkan beratus-ratus kali, mungkin pula lebih dalam pergaulannya yang langsung dengan objek-objek di sekitarnya. Kadang seorang anak telah menguasai suatu kepandaian tertentu, tapi hilang lagi. Ini hanya merupakan suatu kebetulan saja dari berbagai aktifitas anak yang sedang mencoba-coba. Dan memang sering terjadi dengan adanya kebetulan semacam ini timbulah pengertian. Tidak heran bila Pieget berkesimpulan bahwa aktifitas anak yang berhubungan langsung dengan benda-benda yang konkret itu merupakan makanan bagi perkembangan 
|Karmawan

kecerdasan anak. Aktivitas motoriknyalah yang kemudian dimasukkan ke dalam dirinya sebagai aktivitas mental. Dan adalah kewajiban bagi orang tua, guru atau orang dewasa lainnya yang berkepentingan untuk menyediakan kemungkinan yang optimal bagi perkembangan si anak, baik di rumah maupun di sekolah.

Selain faktor di atas, ada lagi faktor lain yang tidak kalah pentingnya, yaitu umur. Pada tiap umur tertentu anak mereaksi secara tertentu. Meskipun umur yang disebut Pieget hanya merupakan patokan yang umum, artinya anak yang lebih cerdas akan lebih cepat sampai pada suatu kemampuan tertentu, dan kebalikannya yang akan terjadi pada anak-anak yang lambat. Kemampuan anak ini harus disertai dengan adanya kematangan, baik dari segi biologis maupun kematangan mental. Jadi tidak dapat kita paksakan pada mereka sesuatu yang belum dapat dikerjakannya, hal ini hampir sama seperti memaksa si lumpuh untuk berjalan. Tapi si anak akan benar-benar menjadi lumpuh perkembangannya kecerdasannya, apabila dia tidak mendapat kesempatan yang baik.

\section{Akibat Harta}

Pengadilan agama di wilayah hukum pengadilan Tinggi Agama Banten dalam menyelesaikan sengketa harta bersama selalu berpatokan terhadap hasil keputusan majlis hakim dan tuntutan para pihak. Jika terjadi adanya putusan perceraian maka hapuslah keadaan harta bersama dan untuk itu dapat diadakan pembagian yang umumnya dilakukan oleh pengadilan agama dengan membagi kedua pihak yang bersengketa fifty-fifty. Dalam hal lain satu pihak akan mendapat keuntungan dari pihak lain, 
maka berdasarkan pasal 222 dan 233, KUHPerdata maka keuntungan dari pihak yang menjanjikan itu harus tetap diberikan kepada pihak yang berhak kecuali pihak yang berhak itu adalah pihak yang salah. Keuntungan yang telah dan dijanjikan merupakan suatu pemberian keuntungan yang akan diberikan oleh pihak ketiga, maka menurut pasal 228 KUH Perdata, perceraian itu tidak menjadikan hapusnya pemberian keuntungan itu. Demikian juga dengan keuntungan yang dijanjikan yang akan diberikan pada anak-anak itu, maka pelaksanaan pemberian keuntungan itu harus dijalankan dengan tidak dipengaruhi oleh perceraian kedua orang tuanya.

Apabila pasangan suami istri bercerai, kemudian masalah gono-gini atau harta bersamanya dilakukan dengan cara musyawarah atau perdamian, maka pembagiannya bisa ditentukan berdasarkan kesepakatan atau kerelaan di anatara mereka berdua. Cara ini sah saja, bahkan ini yang terbai. Pembagian harta gono-gini atau harta bersama dapat ditempu melalui putusan pengadilan agama atau melalui musyawarah. Dalam penyelesaian pembagian harta bersama melalui jalan musyawarah ini, boleh saja mereka sepakat bahwa mantan sumi mendapat sepertiga dari harta bersama, sedangkan mantan istri mendapat dua pertiga sebaliknya, mantan istri mendapat sepertiga, sedangkan mantan suami mendapat dua pertiga. Yang penting, prosentase bagian masing-masing itu, dihasilkan atas dasar musyawarah mufakat dan perdamaian serta tidak ada unsur pemaksaan.

Hukum Islam tidak mengenal lembaga harta bersama. Harta yang diperoleh oleh suami istri merupakan milik mereka 
|Karmawan

masing-masing. Suami istri mempunyai kewenangan untuk melakukan berbagai transaksi atas harta kekayaan masingmasing. Ketentuan demikian diatur dalam Q.S Al-Nisa' [4] : 32. Harta bersama dalam UU Perkawinan sangat jelas, yaitu harta yang diperoleh suami dan/atau istri selama dalam perkawinan kecuali yang diperoleh oleh suami atau istri dari warisan dan hadiah. Dalam KHI terdapat beberapa pasal yang bisa menimbulkan bias pengertian. Dalam Pasal 86 KHI dikatakan "Pada dasarnya tidak ada percampuran antara harta suami dan harta istri karena perkawinan," Pasal ini dapat mengandung pengertian segala harta yang diperoleh suami atau istri baik sebelum dan sesudah perkawinan tidak dengan sendirinya menjandi harta bersama. Sedangkan dalam Pasal 35 ayat (1) UU Perkawinan, segala harta yang diperoleh suami dan/atau istri selama perkawinan menjadi harta bersama kecuali yang diperoleh dari warisan atau hadiah bagi masing-masing suami istri.

Akan tetapi jika terjadi perceraian atau cerai mati, KHI lebih konkrit mengatur cara pembagian harta bersama di mana suami istri yang bercerai mendapat bagian yang sama masingmasing memperolah 1/2 (satu perdua) bagian (Pasal 96 dan 97 KHI). Sedangkan UU Perkawinan tidak mengatur demikian, melainkan jika terjadi perceraian atau cerai mati, pembagian harta bersama dibagi menurut hukum masing-masing. Yang dimaksud hukumnya masing-masing adalah hukum agama, hukum adat dan hukum-hukum lainnya (pasal 37 dan penjelasan Pasal 37 UU Perkawinan). Rumusan pembagian harta bersama dalam Pasal 37 UU Perkawinan tersebut dipengaruhi oleh pemikiran bahwa hukum yang berlaku di Indonesia adalah tiga sistem hukum, yaitu 
hukum Islam, hukum adat dan hukum yang termuat dalam KUHPerdata. Hukum Islam tidak mengenal harta bersama, hukum adat mengenal harta bersama akan tetapi pembagiannya tidak sama di mana suami lebih banyak dari bagian istri, dan KUHPerdata menetapkan bagian suami dan istri sama masingmasing $1 / 2$ bagian.

Penetapan bagian harta bersama masing-masing suami istri mendapat setengah bagian sangat memperhatikan pengarusutamaan gender yang sebelumnya istri dalam hukum Islam tidak mempunyai hak dari harta yang diperoleh suami selama berumah tangga, walaupun istri yang berfungsi sebagai ibu rumah tangga ikut berperan serta melakukan pekerjaanpekerjaan yang secara tidak langsung menciptakan rumah tangga yang sakinah mawaddah wa rahmah. Bahkan agama Islam istri yang bekerja tidaklah wajib, jika itu dilakukan istri pun juga tidaklah dilarang, dalam artian diperbolehkan asalkan memenuhi adab-adab yang Islami. Namun, kerap kali ketika istri ikut berperan mencari nafkah, dan apalagi jika usaha yang dilakukan istri terlihat lancar dan menghasilkan, suami justru menjadi lengah, leha-leha, berpangku tangan, lupa pada kewajiban utama sebagai kepala rumah tangga yakni menafkahi keluarga.

\section{Penutup}

Sebagai penutup dari tulisan ini bahwa pendekatan keagamaan mediator dalam perkara perceraian memberikan warna tersendiri dalam penyelesaian perkara di pengadilan agama, para pihak merasa adanya pengetahuan tentang agama yang diberikan oleh pihak mediator dalam masalah perceraian. 
Sehingga para mengurungkan niatnya untuk berpisah dan mau rukun kembali menjadi keluarga yang utuh karena berbagai alasan yang dijelaskan oleh mediator. Adapun materi pendekatan kegamaan yang diberikan para pihak yang berperkara, terhadap suami istri, jika perceraian terjadi maka berakibat terhadap nafkah dan tanggung jawab sebagai suami istri, dampak perceraian akan menjadi permasalahan terhadap seorang anak menjadi tidak terurus dan berpengaruh terhadap efek psikologis, bahkan anak di bawah umur kekuasaan orang tua akan berakhir dan berubah menjadi perwalian, akibat harta, akan menjadi perselisihan harta bersama sehingga dilakukan dengan cara musyawarah atau perdamaian pembagiannya ditentukan berdasarkan kesepakatan bersama. Wallahu a'lam bishowaab.

\section{Daftar Pustaka}

Abbas, Syahrizal, Mediasi dalam Hukum Syari'ah, Hukum Adat, dan Hukum Nasional (Jakarta: Kencana, 2011).

al-Zuhayli, Wahbah, al-fiqh al-Islami wa Adillatuh, Juz 10, 7405.

Cherlin, Andrew J., Chase-Lansdale, P,. Lindsay dan McRae, Christine. "Effects of Parental Divorce on Mental Health Throughout the Life Course", Journal American Sosiological Review, Vol. 63, No. 2, 1998.

Daradjat, Zakiah, Kesehatan Mental dalam Pendidikan dan Pengajaran, Pidato Pengukuhan Guru Besar Tetap IAIN Syarif Hidayatullah Jakarta pada tahun 1984.

David H. dan Acock, Alan C. "The Impact of Divorce on Children". Journal of Marriage and Family, Vol. 50, No. 3, 1988.

Emery, Robert E. "Divorce mediation: Negotiatings and Renegotiating Relationships" Journal Family Relation, Vol. 44 No. 4, 1995. 
Guo, Guang. dan Harris, Kathleen Mullan. "The Mechanisms Mediating the Effects of Poverty on Children's Intellectual Development”, Journal Demography, Vol. 37, No. 4, 2000.

Harahap, M. Yahya, Hukum Acara Perdata Peradilan Indonesia (Medan: CV. Zahir Trading Co, 1977), 48.

Harrington, Christine B dan Merry, Sally Engle. "Idoelogical Production: The Making of Community Mediation” Journal Law san Society Review, Vol. 22 No. 4, 1988.

Hurlock, Alexander, Psychology an Introduction (USA: Sage Publisher, 1987). Kapinus, Carolyn A. "The Effect of Parental Marital Quality on Young Adults' Attitudes toward Divorce", Journal Sociological Perspectives, Vol. 48, No. 3, 2005.

Larry A. Hjelle dan Daniel J. Ziegler, Personality Theories (Basic Assumption, Research, and Application) (New York: McGraw-Hill, Inc, 1992).

Luepnitz, Deborah A. "Which Aspects of Divorce Affect Children?", Journal The Family Coordinator, Vol. 28, No. 1, 1979.

Morrison, Andrew S. "Is Divorce Mediation the Practice of Law? A Matter of Perspective."Journal California Law Review, Vol. 75, No. 3, 1987.

Munir, M. Ilahi, Wahyu Manajemen Dakwah (Jakarta: Kencana, 2006).

Piaget, Jean, Origins of intelligence in the child ( London: Routledge \& Kegan Paul. 1936).

Rachmawati, Metode Perkembangan Sosial Emosional (Jakarta: Universitas Terbuka).

Richard M. Calkins, Fred Lane, "From Advocate To Peacemaker: Qualities And Techniques Of The Successful Mediator," Illinois Bar Journal 90.

Subhan, Zaitunah, Menggagas Fiqh Pemberdayaan Perempuan (Jakarta: elKahfi, 2008), 265.

Yusuf, Syamsu, Landasan Bimbingan dan Konseling Keluarga (Bandung: Remaja Rosdakarya, 2014). 